NOVEMBER 1974

FOURTEENTH YEAR - No.164
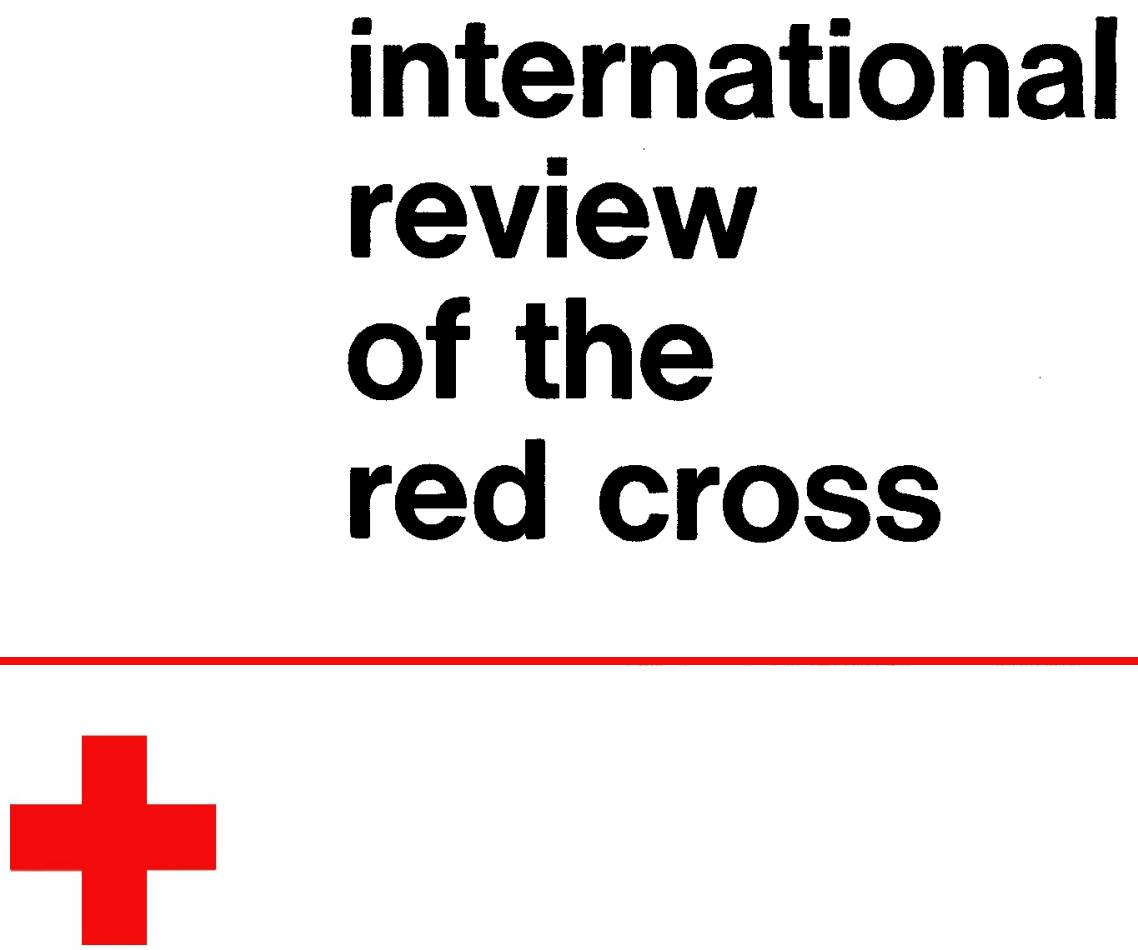

INTER ARMA CARITAS

GENEVA

INTERNATIONAL COMMITTEE OF THE RED CROSS FOUNDED IN 1863 


\section{INTERNATIONAL COMMITTEE OF THE RED CROSS}

Mr. ERIC MARTIN, Doctor of Medicine, Honorary Professor of the University of Geneva President (member since 1973)

Mr. JEAN PICTET, Doctor of Laws, Chairman of the Legal Commission, Associate Professor at the University of Geneva, Vice-President (1967)

Mr. HARALD HUBER, Doctor of Laws, Federal Court Judge, Vice-President (1969)

Mr. HANS BACHMANN, Doctor of Laws, Director of Finance of Winterthur (1958)

Mr. MAX PETITPIERRE, Doctor of Laws, former Swiss Federal Councillor (1961)

Mr. ADOLPHE GRAEDEL, former member of the Swiss National Council, former Secretary-General of the International Metal Workers Federation (1965)

Mrs. DENISE BINDSCHEDLER-ROBERT, Doctor of Laws, Professor at the Graduate Institute of International Studies, Geneva (1967)

Mr. MARCEL A. NAVILLE, Master of Arts, ICRC President from 1969 to 1973 (1967)

Mr. JACQUES F. DE ROUGEMONT, Doctor of Medicine (1967)

Mr. ROGER GALLOPIN, Doctor of Laws, former ICRC Director-General (1967)

Mr. WALDEMAR JUCKER, Doctor of Laws, Secretary, Union syndicale suisse (1967)

Mr. VICTOR H. UMBRICHT, Doctor of Laws, Managing Director (1970)

Mr. PIERRE MICHELI, Bachelor of Laws, former Ambassador (1971)

Mr. GILBERT ETIENNE, Professor at the Graduate Institute of International Studies and at the Institut d'études du développement, Geneva (1973)

Mr. ULRICH MIDDENDORP, Doctor of Medicine, head of surgical department of the Cantonal Hospital, Winterthur (1973)

Miss MARION ROTHENBACH, Master of Social Work (University of Michigan), Reader at the Ecole des Sciences sociales et politiques of the University of Lausanne (1973)

Mr. HANS PETER TSCHUDI, Doctor of Laws, former Swiss Federal Councillor (1973)

Mr. HENRY HUGUENIN, Bank Manager (1974)

Mr. GOTTFRIED DE SMIT, Managing Director (1974)

Honorary members: Mr. JACQUES CHENEVIÈRE, Honorary Vice-President;

Miss LUCIE ODIER, Honorary Vice-President; Messrs. GUILLAUME BORDIER, PAUL CARRY, Mrs. MARGUERITE GAUTIER-VAN BERCHEM,

Messrs. SAMUEL A. GONARD, ÉDOUARD DE HALLER, RODOLFO OLGIATI, PAUL RUEGGER, DIETRICH SCHINDLER, FRÉDÉRIC SIORDET, ALFREDO VANNOTTI.

\section{EXECUTIVE BOARD}

Mr. ROGER GALLOPIN, President

Mr. VICTOR H. UMBRICHT, Vice-President

Mrs. DENISE BINDSCHEDLER-ROBERT

Mr. GILBERT ETIENNE

Dr. ULRICH MIDDENDORP

Mr. JEAN PICTET

Mr. GOTTFRIED DE SMIT

Mr. PIERRE MICHELI, Deputy member 


\section{INTERNATIONAL REVIEW OF THE RED CROSS}

\section{CONTENTS}

INTERNATIONAL COMMITTEE OF THE RED CROSS

\section{MISCELLANEOUS}

NOVEMBER 1974 - No. 164

Danièle Bujard : The Geneva Convention of 1864 and the Brussels Conference of 1874 (II) . . . 575

Jacques Moreillon: The International Committee of the Red Cross and the Protection of Political Detainees . . . . . . . . . . . . 585

Recognition of The Gambia Red Cross Society 596 Conference of Government Experts on Weapons 598 ICRC Action in Cyprus . . . . . . . . . . . 599

External activities:

Africa - Latin America - Asia - Europe Middle East — Japan . . . . . . . . . 608

In Geneva :

Geneva Conventions . . . . . . . . . . . 614

Guests of the ICRC . . . . . . . . . . . . . 614

Publications on the Geneva Conventions . . . 615

The Brussels International Declaration of 1874 concerning the Laws and Customs of War . . 616

Round Table on Present Problems of Humanitarian Law . . . . . . . . . . . . . . . 621

International Institute for Human Rights . . . 622 
FRENCH EDITION OF THE REVIEW

SUPPLEMENTS

TO THE REVIEW

SPANISH

GERMAN

INTERNATIONAL REVIEW OF THE RED CROSS
The French edition of this Review is issued every month under the title of Revue internationale de la Croix-Rouge. It is, in principle, identical with the English edition and may be obtained under the same conditions.

Danièle Bujard: El Convenio de Ginebra de 1864 y la Conferencia de Bruselas de 1874 - Conferencia de expertos gubernamentales sobre las armas - Jacques Moreillon: El Comité Internacional de la Cruz Roja y la protección de los detenidos políticos.

Danièle Bujard: Die Genfer Konvention von 1864 und die Brüsseler Konferenz von 1874 (II) - Die Regierungsexpertenkonferenz über die Waffen - Jacques Moreillon: Das Internationale Komitee vom Roten Kreuz und der Schutz der politischen Häftlinge.

The International Review is published each month by the International Committee of the Red Cross

17, avenue de la Paix, 1211 Geneva, Switzerland Postal Cheque No. 12 - 1767.

Annual subscription: Sw. Fr. 30.- (\$10.-)

Single copy Sw. Fr. 3.- (\$1.-)

EDITOR: J.-G. LOSSIER

The International Committee of the Red Cross assumes responsibility only for material over its own signature. 